\title{
The Manner Result Complementarity and the Lexicalization Pattern of Chinese Motion Verbs ${ }^{*}$
}

\author{
Lei Qiu \\ School of Foreign Languages, Huaiyin Normal University, Huaian, China
}

\begin{abstract}
Rappaport Hovav and Levin (1998, 2010) propose manner/result complementarity hypothesis (MRC), i.e. verbs can not lexicalize manner and result simultaneously at a time. As to the encoding of motion events, Levin et al. (2009) also claim that manner of motion verbs across languages simply lexicalize manner and no direction is entailed. However, three basic motion verbs in Chinese--zŏu 'walk', păo 'run' and fëi 'fly', which are regarded as prototypical manner of motion verbs but also seem to lexicalize directed motion when used in some constructions. Then questions arise: do these verbs lexicalize direction of motion and are they counterexamples of the MRC? Based on evidence gained from a series of linguistic tests, this study argues that on the one hand different from views of Levin et al. (2009), the three manner of motion verbs can indeed lexicalize directed motion, but on the other hand they never encode the manner and direction of motion simultaneously and thus they are not counterexamples of the MRC. The fact that manner of motion verbs exhibiting similar lexicalization pattern can also be found in other languages indicates that the prototypical manner encoded in these verbs may be the conceptual condition for the special lexicalization pattern.
\end{abstract}

Index Terms —-manner/result complementarity, motion verbs, lexicalization pattern

\section{INTRODUCTION}

Are there any constraints on the complexity of verb meaning? Can we explain verbs' varied grammatical behaviors by looking at their meaning? At least to lexical semanticists, the answers to both questions are "yes". As advocates of lexical semantic approach, Rappaport Hovav and Levin (2010) propose that verbs' ontological categorization constrains the complexity of verb meaning and the lexical property of a verb associated with its ontological type is important to determining or constraining its argument expressions. Based on their observation of the meaning components lexicalized in ontologically different types of verbs and their distinct grammatical behaviors, Rappaport Hovav and Levin $(1998,2010)$ suggest a systematic lexical gap in verbal meaning: manner and result meaning components can not be encoded simultaneously and thus the two meaning components are in complementary distribution. Though the proposal of this hypothesis is primarily based on English data, Rappaport Hovav and Levin (2010) also claim that the manner/result complementarity is cross- linguistically relevant.

Lexicalization patterns of motion verbs in Chinese have been studied based Talmy's framework of motion events (Talmy, 1985, 2000). Among many other studies, Lin (2011) investigates lexicalized meaning in Chinese motion verbs in the light of the MRC in particular. Based on her observation of the syntactic distribution of Chinese motion verbs, Lin (2011) argues that the lexicalization patterns of motion verbs in Chinese conform to the MRC. However, some inconsistent grammatical behaviors of three basic motion verbs zǒu 'walk', păo 'run' and fēi 'fly' are neglected by previous researchers. The three verbs, though all regarded as manner of motion verbs by researchers, also behave like directed motion verbs in some constructions. For example, the three verbs can be found in subject inversion construction, as in (1)---a property they share with directed motion verbs such as lái 'come' and qù 'go' in (2), but not with other manner of motion verbs such as tiào 'jump' and pá 'crawl' in (3), as without getting combined with other path morphemes manner of motion verbs generally can not be used in this construction. (Yuan, 1999)

(1) a. Zǒu le yīgèxuésheng.

walk ASP one CL student

A student left.

b. Fèi le $y \bar{l}$ zhī gēzi.

fly ASP one CL pigeon

A pigeon flew away.

(2) a. Lái le yī gè zhíyuán.

come ASP one CL employee

Here came an employee.

b. Qù le yī gè lăo shī.

go ASP one CL teacher

\footnotetext{
* This research is supported by Jiangsu Philosophy and Social Science Fund for Colleges (No. 2018SJA1586). The early version of the paper was presented at $30^{\mathrm{Th}}$ Pacific Asia Conference on Language, Information and Computation.
} 

There went a teacher.
a. *Tiào le yīgèxiăohaí.
jump ASP one CL child
(Intended) a child jumped.
b. *Pá le yi tiáo máomáochóng.
crawl ASP one CL catepillar
(Intended) A caterpillar crawled.

Then questions arise: do these verbs lexicalize directed motion in these cases; are these verbs counterexamples of the MRC? The answers to the questions are important as they can provide direct evidence for or against the cross-linguistic validity of the MRC. The present study intends to have a close look at the lexicalized meaning and grammatical behaviors of the three motion verbs and determine whether they are counterexamples of the MRC in order to further check the cross-linguistic validity of the hypothesis on one hand, and to reveal the possible lexicalization patterns of motion verbs in Chinese on the other. In the following part, the main tenets of the MRC will be presented in Section 2. Previous studies on lexicalization patterns of Chinese motion verbs will also be briefly reviewed in Section 3 before the three motion verbs zǒu 'walk' păo 'run' and fêi 'fly' are discussed in detail in Section 4. Section 5 briefly analyzes the lexicalization pattern of the three verbs in cross linguistic context and concludes the whole study.

\section{THE MANNER RESUlt COMPLEMENTARITY AS A LEXICAL CONSTRAINT}

Assuming the argument realization of a verb is largely determined by event structure decomposition, in particular the association between event schemas and verb roots, Rappaport Hovav and Levin (1998, 2010) propose the ontological categorization of verb roots such as manner or result determines the way the root integrates into an event schema and that a root can only be associated with a single position in an event, as is illustrated in (4). Since manner and result roots occupy distinct positions in event schemas: manner roots are modifiers of the primitive predicate ACT and result roots are arguments of BECOME, the MRC follows.

(4) a. [x ACT<MANNER>]

b. [[x ACT] CAUSE [y BECOME <RESULT>]]

Rappaport Hovav and Levin (2010) also refine the semantic notions of manner and result verbs as involving non-scalar and scalar changes. In both change-of-state and motion domains result verbs involve scalar changes, as they lexicalize change in the value of some scalar attribute, while manner verbs lexicalize non-scalar changes which are complex and cannot be characterized by an ordered set of values of a single attribute.

The MRC is claimed to be grammatically relevant as manner and result verbs show distinct argument realization patterns and aspectual features. For example, manner rather than result verbs allow unspecified or unsubcategorized objects. While manner verbs are generally atelic activity verbs, result verbs associated with two-point scales are necessarily punctual and telic. Even result verbs involving multiple-point scales can be interpreted telically without supporting context. (Rappaport Hovav, 2014)

\section{Previous Studies on the LeXiCAlization PATterns of Chinese Motion Verbs}

Rappaport Hovav and Levin's proposal of the MRC is also consonant with Talmy's well-known classification of motion verbs based on what semantic component--path vs. manner--is conflated into the verb. Lexicalization patterns of Chinese motion verbs have been studied mainly based on Talmy's framework. However, as Lin (2011) points out, motion verbs in Chinese are classified primarily via an intuition-based semantic grouping, so there are some controversies over some less prototypical motion verbs. For example, in Guo and Chen (2009), zuān 'squeeze/get into' and diào 'fall' are classified as manner of motion verbs but directed motion verbs in Lamarre (2008). Some motion verbs such as dēng 'climb' and táo 'escape' are also cited as counterexamples of the MRC to encode both manner and direction of motion (Ma, 2008; Shi, 2014). Therefore it is necessary to reexamine the classification of Chinese motion verbs based on systematic and consistent criteria.

Based on the lexical property of manner and result verbs suggested by Rappaport Hovav and Levin (2010), Lin (2011) introduces several tests to identify manner or direction of motion verbs via their syntactic distribution. For example, according to Lin (2011), manner and direction of motion verbs exhibit different compatibility with other elements expressing manner or result: only manner of motion verbs are compatible with a variety of result and path phrases and only directed motion verbs can be modified by various manner adverbials or co-occur with a variety of manner verbs. As illustrated in (5), tiào 'jump' as a manner verb is compatible with a variety of path and result phrases such as chū 'exit' and duàn tuǐ 'break legs'. Nevertheless, it can not be modified by adverbials or verbs expressing other manners such as gŭn 'roll' or pá 'crawl'.

(5) a. Tā tiào-chū-le shuǐkēng he jump-exit-ASP puddle

'He jumped out of the puddle.'

b. Tā tiào-duàn-le tǔ̆ he jump-break-ASP leg 


$$
\begin{aligned}
& \text { 'His leg was broken as a result of his jumping.' (Peck et al., 2013, p.683) } \\
& \text { c. Tà gǔn/pá tiào } \\
& \text { he roll/crawl jump } \\
& \text { (Intended) 'He jumped by rolling /crawling.' }
\end{aligned}
$$

However, directed motion verbs show contrastive grammatical behaviors. For example, directed motion verb huí 'recede', as illustrated by Lin (2011) in (6), can co-occur with a variety of manner verbs such as gŭn 'roll' and tiào 'jump', but it is incompatible with path or result phrases which are not related to the path lexicalized in the verb itself.

(6) a. Dírén tiào/gǔn-zhe huí guānwài enemy jump/roll-IMP return pass.outside

'The enemy returned to the outside of the pass jumping/rolling'

b. *Dírén huí-lèi le

enemy return-be.tired ASP

(Intended) 'The enemy became tired as a result of returning' (Lin, 2011, p.37)

As can be seen, linguistic tests introduced by Lin (2011) can distinguish manner of motion and directed motion verbs in Chinese in a consistent manner so far. However, when we check the actual uses of the three manner of motion verbs zǒu 'walk' păo 'run' and fèi 'fly', they also pose a problem to Lin's tests: though in their basic uses they can pass the tests for manner of motion verbs, in some other cases their syntactic distribution just contradicts the property of manner of motion verbs. For example, as prototypical manner of motion verbs, they are not expected to co-occur with other manner verbs, since verbs specifying different manners should not be compatible. Nevertheless, as illustrated in (7), in their actual uses they can co-occur with other manner verbs. In (7a) zǒu 'walk' co-occurs with another manner verb piāo 'float', in (7b) păo 'run' also co-occurs with another manner verb gŭn 'roll' and in (7c) fēi 'fly' follows another manner verb tī 'kick'.

(7) a. Qìqu piāo-zǒu le.

balloon float-walk ASP

'The balloon flew away.'

b. Píqíu gǔn-păo le.

rubber ball roll-run ASP

'The rubber ball rolled away.'

c. Xiézi beì tì-fêi le.

shoe PASS kick-fly ASP

'The shoe was kicked away.'

The inconsistent grammatical behaviors of these verbs illustrated in (7), together with the evidence that they can enter subject inversion construction as mentioned in Introduction section force us to ask whether they can indeed encode direction of motion and then contribute to counterexamples of the MRC. Following the tenets of the MRC and Lin's (2011) study I will look at the semantics and grammatical behaviors of these verbs in detail to clarify their ontological status in next section.

\section{CASe Studies of Motion Verbs ZǑU 'WALK’ PăO 'Run’ AND FËI 'Fly'}

In this section, the lexicalized meaning components and the grammatical properties of the three motion verbs zǒu 'walk' păo 'run' and fêi 'fly' will be looked at in detail. Besides using Lin's linguistic tests to distinguish manner verbs from result verbs, I will also take the aspectual property of manner and direction of motion verbs into account, as different aspectual features of manner and result verbs are also crucial to their syntactic distribution. As mentioned in Section 3, Rapapport Hovav and Levin (2010) suggest distinct scalar notions underlying manner and result verbs. In case of motion verbs, manner of motion verbs encode non-scalar changes, they are atelic. Directed motion verbs can be further divided into two subtypes depending on whether they entail two-point or multi-point scalar changes: verbs lexicalizing two-point scalar changes are necessarily telic and punctual and verbs lexicalizing multi-point scales have either telic or atelic readings depending on contexts.

\section{A. Zǒu 'Walk'Păo 'Run' and Fèi 'Fy'Used as Manner of Motion Verbs}

In their basic uses, there is no doubt that the three verbs show hallmarks of manner verbs. As they lexicalize non-scalar changes, they are necessarily atelic and compatible with durative time adverbial. As illustrated in (8a), zǒu 'walk' is compatible with durative time adverbial sān gè xiăoshí 'three hours'. In ( $8 b)$ fêi 'fly' can be used with durative time adverbial sān tiān 'three days'.

(8) a. Tā zǒu le sān gè xiăoshí he walk ASP three CL hour 'He walked for three hours.'

b. Xiăoniăo fēi le sāntián little bird fly ASP three days

'The little bird flew for three days'

Since they do not entail any direction or result information, they can take as their complements varied result and path 
phrases. As illustrated in (9a), păo 'run' is compatible with both upward and downward directions. It is also shown that in (9b) fềi 'fly' can take duàn 'break (wings)' and in (9c) păo 'run' can take dīu xié 'lose shoes' as their resultant complements respectively.

(9) a. Zhànshi měitiān păo-shàng-păo-xià

soldier everyday run-ascend-run-descend

'Soldiers run up and down every day.'

b. Tā-men de chìbăng dōukuaì fêi-duàn le

they-PL DE wings almost fly-break ASP

'They (pigeons) almost broke their wings as a result of flying (continuously)'

c. Tà păo-dìu xiézi le

he run-lose shoe ASP

'He lost his shoes as a result of running'

To conclude, it can be seen that in their basic uses the lexicalized meaning and grammatical behaviors of the three verbs conform to the property of manner of motion verbs.

\section{B. Zǒu 'Walk'Păo 'Run' and Fèi 'Fy'Used as Directed Motion Verbs}

As mentioned in previous sections, the three verbs can be found to exhibit grammatical behaviors distinct from manner of motion verbs, as they can be used in subject inversion construction and they can also follow another manner of motion verb to form a verbal compound without contradiction. Focusing on the two specific cases, this section uses a series of syntactic and semantic tests to check what lexical meaning they actually encode and to clarify their ontological status.

First, I will show when the three motion verbs are used in subject inversion constructions they only encode directed motion and their manner of motion sense is dropped out. In Chinese, it is generally accepted by scholars (Huang, 1990; $\mathrm{Li}, 1990$; Yu, 1995) that verbs which are used with perfective aspectual marker in subject inversion construction are prototypical unaccusative verbs. These verbs generally describe non-volitional change-of-state/location of the theme. As illustrated in (10a), the verb sǐ 'die' describing a non-volitional change of state is unaccusative verb, so it can be used in the subject inversion construction. Nevertheless in (10b) chàng 'sing' expressing a volitional action is an unergative verb, so it can not be used in the construction.

(10) a. Sì le yí gè rén

die ASP one CL person

'A person died.'

b. *Chàng le yígè rén.

Sing ASP one CL person

(Intended) 'A person sang.'

Though generally manner of motion verbs are regarded as unergative verbs which without getting combined with other path morphemes can not enter the subject inversion construction, the three verbs can be used in the construction, as shown in the example sentences of (1).

With regard to these cases I suggest that these verbs entail only the directed motion as 'being away from the reference object'. Crucially as is shown by their grammatical properties in this construction, they lose their manner meaning components. First, when they are used in this construction, they lose the atelic aspectual feature of manner verbs and encode punctual and telic changes. The examples in (11) show that they are not compatible with durative aspectual marker zhe.

(11) *a. Zǒu zhe yígèxuésheng

walk DUR one CL student

(Intended) 'A student is leaving.'

*b. Păo zhe yí gè fànrén

run DUR one CL prisoner

(Intended) 'A prisoner is running away'

*c. Fèi zhe yí zhī gēzi

fly DUR one CL pigeon

(Intended) 'A pigeon is flying away.'

In addition, when the three verbs are used in subject inversion construction they can not be modified by subject-oriented manner adverbials, as shown in (12). This also indicates that the manner of motion sense of the verbs is dropped out and they only encode the directed motion sense.

(12) *a. Xùnsù de zǒu le yí gèxuésheng swiftly DE walk ASP one CL student (Intended) 'A student left swiftly'.

*b. Pīnming de păo le yí gè fànrén desperately DE run ASP one CL prisoner (Intended) 'A prisoner ran away desperately'

*c. Mĭnjié de fềi le yì zhīgēzi 
nimbly DE fly ASP one CL pigeon

(Intended) 'A pigeon flew away nimbly'

Another case that the three verbs show distinct grammatical behaviors from manner of motion verbs is when they follow another verb to form verbal compounds, as shown in (7). Based on Chinese morphology when two verbs co-occur to form a verbal compound there are mainly three types of possible relationship between the two component verbs: i.e. coordination, modification, and resultative relation (Packard, 2000). The grammatical behaviors of these verbal compounds in (7) show that they are actually resultative verbal compounds ruling out the other two possibilities. On the one hand the two component verbs express distinct manners which are incompatible to each other and thus they can not hold coordinating relation. On the other hand, the two component verbs do not hold modifying relation either, since for this kind of verbal compounds in which the first verb (V1) functions as an adverbial to further specify the action denoted by the second verb (V2) (e.g. fēi-bēn fly-run 'to run (quickly) like flying') it is not possible to add the negation marker bu in between to form potential constructions (e.g. *fēi-bu-bēn 'fly-NEG-run' '\#not be able to run by flying'). However the verbal compounds in (7) can do so, as shown in (13), which is just one of the properties shared by resultative verbal compounds in Chinese. Thus it is clear that the component verbs in (7) hold resultative relation.

(13) piāo-bu-zǒu

float-NEG-walk

'not be able to float away'

As for motion events, the two juxtaposing verbs form directional verbal compounds (henceforth DVC), a subtype of resultative verbal compounds in which V1 usually specifies the manner or cause of the motion and V2 expresses the direction of motion. In case of verbal compounds in (7), the verbs holding V1 position piāo 'float', gǔn 'roll' and tī 'kick' specify the manner of motion, and the verbs occupying the V2 position zǒu 'walk' and páo 'run' describe the direction of the motion.

This analysis is supported by the contrastive semantic entailments of example sentences in (14) and (15). As shown in (14), the manner of motion verbs piāo 'float', gŭn 'roll' and tī 'kick' do not entail displacement of the theme. In the sentence of (14a), piāo 'float' describes that flags were floating on the top of the pole where flags were tied and thus no displacement was possible. Similarly, in (14b) gǔn 'roll' and tī 'kick' describe actions in place, so there is no displacement either.

(14) a. Qígān shàng piāo zhē xiăo qí

flagpole LOC float IMP small flag

'small flags were floating on the top of the pole'

b. Tā zài yuándì gǔn/tī

he at original place kick/roll

'He rolled/kicked in place.'

Nonetheless, when zŏu 'walk' păo 'run' and fēi 'fly' are added following these verbs to form verbal compounds, displacement of the theme as 'being away from the deictic object' is entailed. In (15a) piāo-zǒu 'float-walk' entails that the flags floated away and they were not on the top of the pole anymore. Similarly, the verbal compounds gŭn-păo 'roll-run' and tī-fêi 'kick-fly' also entail the themes have left the deictic object, as illustrated in (15b) and (15c).

(15) a. Xiăo qi piāo-zŏu le,

small flag float-walk ASP,

* dàn tā hái zài qígān shàng.

but it still at flagpole LOC

'Flags floated away, \#but they were still on the top of the pole.'

b. Píquiu gǔn-păo le,

rubber ball roll-run ASP

*dàn tā hái zài yuándì.

but it still at original place

'The rubber ball rolled away, \#but it still stays at its original place.'

c. Xiézi beì tī-fềi le,

shoe PASS kick-fly ASP

*dàn xiézi hái zài jiăo shàng

but shoe still at foot LOC

'The shoe was kicked off, \#but it was still on the foot.'

Distinct lexical entailments can also be attested by looking at the aspectual features of these DVCs. As illustrated in (16), when the three verbs are used as V2 to form DVCs, these DVCs are incompatible with the progressive aspectual marker zhèngzài and durative aspectual marker zhe. This indicates that though all the components verbs of these DVCs are typically atelic, these DVCs have lost their atelic aspectual feature and become telic.

(16) a. *Qìqiu zhèngzài piāo-zǒu zhe.

balloon PROG float-walk DUR

(Intended) 'The ballon is floating away.'

b. *Píqíu zhèngzài gǔn-păo zhe. 
rubber ball PROG roll-run DUR

(Intended) 'The rubber ball is rolling away'

c. *Xiézi zhèngzài beì tī-fêi zhe.

shoe PROG PASS kick-fly DUR

(Intended) 'The shoe is being kicked off.'

The change of aspectual feature can also be supported by the contrastive readings of the post-verbal adverbial 'for $\mathrm{X}$ time' when it co-occurs with only the manner verbs in V1 position or with the DVCs. To be specific, as in (17) when the manner verbs holding V1 position co-occur with a post-verbal adverbial 'for X time', there is only an atelic process reading.

(17) a. Qiqiu piāole ȳ̄xiăoshíle.

balloon float PERF one hour ASP

'The balloon has floated for an hour.'

b. Píqíu gǔnle yīfēnzhōngle.

rubber ball roll PERF one minute ASP

'The rubber ball has rolled for a minute.'

c. Xiézi beì tī le ȳ̄fēnzhōngle.

shoe PASS kick PERF one minute ASP

'The shoe has been kicked for a minute.'

In contrast, when the post-verbal adverbial 'for X time' co-occurs with the DVCs, the time period indicated by the adverbial only has a 'after $\mathrm{X}$ time' reading which specifies the length of time the result state of 'being away from the reference object' holds; see (18). This further indicates that the DVC as a whole describes a two-point scalar change.

(18) a. Qìqúu piāo-zǒu le yīxiăoshíle.

Balloon float-walk PERF one hour ASP

'It had been an hour since the balloon floated away.'

b. Píqíu gǔn-păole yīfēnzhōngle.

rubber ball roll-run PERF one minute ASP

'It had been a minute since the rubber ball rolled away.'

c. Xiézi bèi tī-fēile yīfēnzhōngle.

shoe PASS kick-fly PERF one minute ASP

'It had been a minute since the shoe was kicked off.'

Thus it is safe to believe that the change of the aspectual feature from atelic to telic is attributed to the three verbs holding V2 position and these verbs have dropped their manner sense. The puzzling problem that the three verbs violate Lin's linguistic tests for manner of motion verb is also clear now. In these cases, the three verbs do not encode the manner of motion at all, and instead they only express the direction of the motion. That's why they can co-occur with another manner of motion verb without contradiction.

Summarizing, when the three prototypical manner of motion verbs exhibit different grammatical behaviors, they also lexicalize distinct meaning components. To be specific, when used in subject inversion constructions and when they follow another manner of motion verb to form a DVC, they lose their manner sense and lexicalize only the sense of directed motion.

\section{Two Distinct Senses of Zǒu 'Walk'Păo 'Run' and Fèi 'Fy' in Complementary Distribution}

Some may argue the directed motion sense of the three motion verbs may not be the lexical entailment of the verb, and it may be derived from the meaning of the construction they are found in or from other pragmatic factors. In Section 4.2 the directed motion sense of the three verbs has been examined based on two typical constructions in Chinese, so it is natural to assume that the directed motion sense is derived from the constructions. In addition, Levin et al. (2009) argue that cross-linguistically manner of motion verbs share the same type of verb root: they all specify only the manner of motion and the sense of directed motion arises from pragmatic factors. However, I suggest neither case is true for the three motion verbs in Chinese. The directed motion sense is not derived from other elements of the sentence and it is indeed the lexicalized meaning in the verbs because the three verbs can have directed motion reading even though they are not used in the two constructions and without pragmatic support from context. For example, as illustrated in (19), without any contextual support the simple sentence with the verb zǒu 'walk' as its only verb is ambiguous. It has two possible interpretations: either 'I am capable of walking.' or 'I can leave'. Therefore, it can be seen that the directed motion sense is not derived from the two constructions; rather it is because the three verbs can possibly lexicalize directed motion that they can enter the two constructions.

(19) Wǒ néng zǒu le

I can walk ASP

a. 'I am capable of walking.'

b. 'I can leave.'

Interestingly, with the former reading 'I am capable of walking' the verb zǒu 'walk' only encodes the manner of motion and for the latter reading 'I can leave' the verb only lexicalizes directed motion as 'leaving the deictic center'. Though the verb can potentially encode both manner and direction of motion, the sentence never entails 'I can leave by 
walking'. In fact, it is just the direct evidence for the MRC as a general principle constraining how much meaning a verb can possibly lexicalize. Following Levin and Rappaport Hovav (2013), a lexicalized meaning component is one which is entailed across all uses of a verb. Though the three motion verbs can potentially lexicalize manner and result, but there is never a single use of the verb which entails both meaning components together.

\section{DISCUSSION AND CONCLUSION}

Though based on the analysis above it is clear that the three motion verbs do lexicalize two types of meaning components in a complementary way, some questions are still open to answer. For example, could we find other Chinese motion verbs which show similar lexicalization pattern? If the answer is no, why do these verbs but not others show the lexicalization pattern? If one only looks at the Chinese lexicon from a synchronic perspective, it is difficult to find any clue to the special lexicalization pattern exhibited by the three verbs. Nevertheless, their special lexicalization pattern should not be considered as coincidence, since there is cross-linguistic evidence that motion verbs conveying similar conceptual meaning components also show a dual way of lexicalization pattern in languages such as Italian, Spanish, Urdu/Hindi, etc. One probable explanation could be that these verbs are most frequently used motion verbs lexicalizing the basic way or gait of motion conceptualized in human mind and due to the high use frequency the manner conveyed in these verbs gradually becomes unmarked light information and in this case these verbs are more likely to convey directed motion sense. As linguists observe, for example, some basic manner of motion verbs show a dual way of auxiliary selection based on their lexical semantic features in Romance and Germanic languages (Sorace 2000; Keller 2000). As seen in (20), in Italian the manner of motion verbs volare 'fly' and correre 'run' can be used to convey the directed motion sense when they are followed by directional compound prepositions and this is in particular indicated by their distinct auxiliary selection of essere different from their basic uses in which they select the auxiliary avere.

(20) a. La rondine *ha/è volata al nido.

the swallow has/is fly.PSTPRT at.the nest

'The swallow has flown to the nest.'

b. Giorgio *ha/è corso fino all'università

Giorgio has/is run.PSTPRT up.to.the university

'Giorgio has run up to the university.' (Levin et al., 2009, p2)

Similarly, in Spanish the directed motion sense can also be read when manner of motion verbs caminar 'walk' and correr 'run' are in composition with prepositional phrases, as can be seen in (21)

(21) a. Michel corre al molino y destruye el cementerio.

Michel run to.the mill and destroy the cemetery

'Michel runs to the mill and destroys the cemetery.' (Levin et al., 2009, p2)

b. ... camino' otra vez al salón

walked again to.the sitting.room

's/he walked again to the sitting room'

(CREA corpus; cited in Levin et al., 2009, p2)

More strikingly, as Hautli-Janisz (2015) observes, motion verbs calna 'walk' and bhagna 'run' in Urdu/Hindi exhibit very similar lexicalization pattern as the three Chinese motion verbs zǒu 'walk', păo 'run' and fēi 'fly' with respect to the manner/result complementarity. The two verbs can express either manner or direction of motion sense, but realize only one depending on the companion verb in the motion complex predicates. In (22a), the verb calna 'walk', when combined with a scalar path verb like ghUsna 'enter', expresses the manner of continuous movement. In contrast, when combined with a manner verb like Urna ' $\mathrm{fly}$ ' as in (22b), it adds a direction of motion interpretation to the nonscalar event of flying.

(22) a. sand makan $=m^{\sim} \quad g^{h}$ Us cal-a

ox.M.Sg.Nom house.M.Sg=in enter move-Perf.M.Sg

'An ox got into the house.'

b. patang ur cal-i

kite.F.Sg fly walk-Perf.F.Sg

'The kite flew away.'

(Hautli-Janisz, 2015, p51)

Interestingly, Hautli-Janisz (2015) notes that only the two verbs calna 'walk' and bhagna 'run' exhibit the special lexicalization pattern in Urdu/Hindi, the same as the case with verbs zǒu 'walk', păo 'run' and fêi 'fly' in Chinese. Thus it can be seen that though within a certain language motion verbs showing a dual way of lexicalization pattern seem to be isolated and coincidental, cross linguistic evidence indicates that basic manner motion verbs tend to exhibit this lexicalization pattern as they all convey prototypical manner or gait of motion which more often than not leads to displacement. This probably explains the conceptual motivation for the lexicalization pattern of these verbs.

Focusing on three Chinese motion verbs zǒu 'walk', păo 'run' and fēi 'fly', this study investigates the lexicalization patterns of Chinese motion verbs. Different from the view of Levin et al. (2009) that manner of motion verbs only 
lexicalize the sense of manner, I suggest the three Chinese motion verbs can indeed lexicalize direction of motion. However, they never encode manner and direction of motion simultaneously and thus do not falsify the MRC. The MRC is a valid cross-linguistic principle that constrains the possible lexicalization patterns of the lexicon. As far as the actual uses are concerned the lexicalization pattern of these three verbs confirms the validity of MRC as a significant observation about how much meaning can be lexicalized in a verb. Though the lexicalization pattern of these verbs seem to be isolated cases in Chinese lexicon, motion verbs exhibiting similar lexicalization pattern can be found in other languages such as Italian, Spanish and Urdu/Hindi. The fact that these verbs conveying similar conceptual meaning components indicates that the lexicalization pattern of these verbs may be influenced by the prototypical manner encoded in the verbs, frequency of language use, pragmatic inference etc.

\section{REFERENCES}

[1] Chen, Liang and Jiansheng Guo. (2009). Motion events in Chinese novels: Evidence for an equipollently-framed language. Journal of Pragmatics, 41:1749-1766.

[2] Hautli-janisz, Annette. (2015). Urdu/hindi complex predicates of motion and the manner/result complementarity. Journal of South Asian Linguistics, 7:39-58.

[3] Huang, C-T. James. (1990). Two kinds of transitive verbs and two kinds of intransitive verbs in Chinese In Proceedings of the Second International Conference on Chinese Teaching, ed, Ting-Chi Tang et al., 39-59. Taipei: World Chinese Press.

[4] Keller, Frank. (2000). Gradience in grammar: Experimental and computational aspects of degrees of grammaticality. Edinburgh, Scotland: University of Edinburgh dissertation.

[5] Lamarre, Christine. (2008). The linguistic categorization of deictic direction in Chinese: With reference to Japanese. In Space in languages of China: Cross-linguistic, synchronic and diachronic perspectives, ed. Dan Xu, 69-98. Dordrecht: Springer.

[6] Levin, Beth, and Malka Rappaport Hovav. (1995). Unaccusativity: At the syntax-lexical semantics interface. Cambridge: MIT Press.

[7] Levin, Beth, John Beavers and Shiao Wei Tham. (2009). Manner of motion roots across languages: Same or different? Handout, Workshop on roots, University Stuttgart, Germany, June, 2009.

[8] Levin, Beth, and Malka Rappaport Hovav. (2013). Lexicalized meaning and manner/result complementarity. In Studies in the composition and decomposition of event predicates. ed. Boban Arsenijevic, Berit Gehrke, Rafael Marin, 49-70. Dordrecht: Springer.

[9] Li, Y.-H. Audre. (1990). Order and Constituency in Mandarin Chinese. Dordrecht: Kluwer Academic.

[10] Lin, Jingxia. (2011). The encoding of motion events in Chinese: Multi-morpheme motion constructions. Stanford: Ph.D. dissertation, Stanford University.

[11] Ma, Yunxia. (2008). The development of Chinese path verbs and motion event expressions. Beijing: Zhongyang minzu daxue Press.

[12] Packard, Jerome L. (2000). The morphology of Chinese. Cambridge \& New York: Cambridge University Press.

[13] Peck, JeeYoung, Jingxia Lin, and Chaofen Sun. (2013). Aspectual classification of Mandarin Chinese verbs: A perspective of scale structure. Language and Linguistics, 14(4): 663-700.

[14] Rappaport Hovav, Malka, and Beth Levin. (1998). Building verb meanings. In The projection of argument structures: Lexical and compositional Factors, ed. M. Butt and W. Geuter, 97-134. Stanford, CA: CSLI Publications.

[15] Rappaport Hovav, Malka, and Beth Levin. (2010). Refections on manner/result complementarity. In Syntax, lexical semantics, and event structure, ed, Edit Doron, Malka Rappaport Hovav, and Ivy Sichel, 21-38. Oxford: Oxford University Press.

[16] Rappaport Hovav, M. (2014). Building Scalar Changes, in The Syntax of Roots and the Roots of Syntax, ed, A. Alexiadou, H. Borer, and F. Sch"afer, 259-281. Oxford: Oxford University Press.

[17] Shi, W., and Wu, Y. (2014). Which way to move: The evolution of motion expressions in Chinese. Linguistics, 52(5):1237-1292.

[18] Sorace, Antonella. (2000). Gradients in auxiliary selection with intransitive verbs. Language 76. 859-890.

[19] Talmy, Leonard. (1985). Lexicalization patterns: Semantic structure in lexical forms. In Language typology and syntactic description 3: Grammatical categories and the lexicon, ed. Timothy Shopen, 57-149. Cambridge: Cambridge University Press.

[20] Talmy, Leonard. (2000). Toward a cognitive semantics, volume II: Typology and process in concept structure. Cambridge: MIT Press.

[21] Yu, Ning. (1995). Towards a definition of unaccusative verbs in Chinese. In Proceedings of the 6th North American Conference on Chinese Linguistics, ed, Jose Camacho and Lina Choueiri, 339-353. Los Angeles: University of South California.

[22] Yuan, B. (1999). Acquiring the unaccusative /unergative distinction in a second language: Evidence from English-speaking learners of L2 Chinese. Linguistics, 37: 275-296

Lei Qiu was born in Shandong, China. She received her master's degree in linguistics and applied linguistics at Northeastern University, China in 2007. She received her doctoral degree in international cultural studies at Tohoku University, Japan in 2017. Now she is an EFL teacher at the School of Foreign Languages, Huaiyin Normal University. Her academic interests include lexical semantics and foreign language teaching. 